\title{
Identifikasi Penyebab Kematian Massal Ikan Gurami (Osphronemus gouramy) Di Sentra Budidaya Ikan Gurami, Desa Beji, Kecamatan Kedung Banteng, Kabupaten Banyumas, Jawa Tengah.
}

\section{Identification of Causes of Mass Death Of Gurami Fish (Osphronemus gouramy) In Gurami Fish Cultivation Sentra, Desa Beji, Kedung Banteng District, Banyumas District, Central Java}

\author{
Ach. Khumaidi ${ }^{1 *}$, Aris Hidayat $^{2}$ \\ ${ }^{1}$ Fakultas Sains dan Teknologi, Universitas Ibrahimy, Kabupaten Situbondo \\ ${ }^{2}$ Widyaiswara Balai Pendidikan dan Pelatihan Aparatur Sukamandi \\ *Email: ach.khumaidi@gmail.com
}

\begin{abstract}
Abstrak
Kasus kematian massal ikan Gurami di Sentra Budidaya Ikan Gurami, Desa Beji, Kecamatan Kedung Banteng, Kabupaten Banyumas, Jawa Tengah berdampak pada menurunnya produksi telur dan benih ikan Gurami. Penelitian ini bertujuan untuk mengidentifikasi patogen penyebab kematian pada ikan Gurami. Metode yang digunakan metode survei dengan pengambilan sampel secara acak, kemudian diidentifikasi keberadaan patogen pada sampel ikan Gurami. Hasil identifikasi patogen pada ikan Gurami menunjukkan adanya infeksi Bakteri (Aeromonas hydrophila, Aeromonas sobria), Parasit (Henneguya sp., Trichodina sp., Vorticella sp.) dan Jamur (Aspergillus sp.). Penelitian ini menunjukkan bahwa kematian massal pada ikan Gurami disebabkan oleh serangan bakteri, parasit, dan jamur.
\end{abstract}

Kata Kunci: ikan Gurami, kematian massal, bakteri, parasit, jamur.

\begin{abstract}
The case of the mass death of Gurami fish at the Center for Cultivation of Gurami Fish, Beji Village, Kedung Banteng Subdistrict, Banyumas Regency, Central Java resulted in a decrease in the production of Gurami fish and eggs. This study aims to identify pathogens that cause death in Gurami fish. The method used is a survey method with random sampling, then identified the presence of pathogens in Gurami fish samples. The results of identification of pathogens in Gurami fish showed a bacterial infection (Aeromonas hydrophila, Aeromonas sobria), Parasites (Henneguya sp., Trichodina sp., Vorticella sp.) And Fungi (Aspergillus sp.). This study shows that mass deaths in Gurami are caused by bacteria, parasites, and fungi.
\end{abstract}

Keywords: Gurami fish, mass death, bacteria, parasites, fungi. 
Journal of Aquaculture Science

DOI: https://doi.org/10.31093/joas.v3i2.53
April 2018 vol 3 (2): 46-54

Online pada http://joas.co.id

\section{PENDAHULUAN}

Ikan Gurami (Osphronemus gouramy) merupakan salah satu spesies ikan air tawar yang memiliki nilai ekonomi yang tinggi dengan kisaran harga antara Rp. $24.000-$ $30.000 / \mathrm{kg}$. Tingginya nilai ekonomi ini menjadi alasan banyaknya para pembudidaya ikan membudidayakan O. gouramy. Ada beberapa macam sistem budidaya yang diterapkan antara lain berupa sistem tradisional dan semi intensif. Namun, sistem budidaya yang umum digunakan adalah berupa budidaya sistem tradisional (Malika et al., 2012).

Kabupaten Banyumas dikenal sebagai kabupaten dengan produksi ikan Gurami yang tinggi, baik dari segi penghasil telur, benih, dan ukuran konsumsi. Menurut Rudiono et al. (2013), produksi budidaya ikan Gurami pada tahun 2010-2011 mengalami kenaikan meskipun belum mencapai target. Ikan Gurami juga menjadi ikan air tawar unggulan kabupaten Banyumas karena memiliki nilai ekonomis yang cukup tinggi (Effendi et al., 2006).

Produksi ikan Gurami pada 2017 mengalami penurunan drastis. Hal ini disebabkan oleh menurunnya kualitas telur yang berdampak pada minimnya telur yang menetas, dan matinya induk ikan Gurami. Faktor kualitas air seperti kekeruhan mempengaruhi tingkat penetasan telur (Ismail dan Khumaidi, 2016). Faktor lingkungan diduga yang menyebabkan ikan menjadi stres dan adanya serangan patogen penyebab penyakit. Serangan penyakit pada budidaya ikan merupakan masalah yang sangat serius (Sarjito et al., 2013). Pada periode Agustus November 2017 di sentra budidaya ikan Gurami, Desa Beji, Kecamatan Kedung Banteng, Kabupaten Banyumas, Jawa Tengah terjadi kematian induk ikan Gurami dengan tingkat mortalitas 90\%. Kondisi ini akan berpengaruh terhadap produksi telur dan benih ikan. Pada tahun 2013, penelitian kematian massal ikan Gurami di beberapa daerah di Indonesia yaitu Jawa Timur, Jawa Tengah, dan Bali menunjukkan bahwa penyebab utamanya adalah serangan giant gourami iridovirus (GGIV) (Koesharyani dan Gardenia, 2013). Kematian massal ikan Gurami juga dapat dipengaruhi oleh serangan Aeromonas (Tanjung et al., 2013) 
Journal of Aquaculture Science

DOI: https://doi.org/10.31093/joas.v3i2.53
April 2018 vol 3 (2): 46-54

Online pada http://joas.co.id serta rendahnya kualitas air pada media budidaya (Putri et al., 2016).

Berdasarkan permasalahan tersebut maka penelitian ini dilakukan untuk mengetahui penyebab pasti penyakit yang terjadi pada ikan Gurami di sentra budidaya ikan Gurami, Desa Beji, Kecamatan Kedung Banteng, Kabupaten Banyumas, Jawa Tengah.

\section{METODE PENELITIAN}

\section{Tempat dan waktu penelitian}

Penelitian ini dilakukan di sentra budidaya ikan Gurami, Desa Beji, Kecamatan Kedung Banteng, Kabupaten Banyumas, Jawa Tengah pada bulan Agustus 2017 - Januari 2018.

\section{Angka kematian induk ikan Gurami}

Angka kematian induk ikan diperoleh dengan metode wawancara kepada para pembudidaya ikan Gumai di Desa Beji.

\section{Identifikasi patogen}

Sampel induk ikan Gurami yang digunakan sebanyak 72 ekor (masing-masing 6 ekor/ lokasi budidaya) dengan gejala klinis terserang penyakit. Metode penelitian dilakukan dengan metode survei dengan teknik pengambilan sampel secara acak. Kemudian lakukan identifikasi patogen di Stasiun Karantina Ikan, Pengendalian Mutu dan Kamanan Hasil Perikanan Kelas II Cirebon. Identifikasi patogen menggunakan metode uji SKIPM Cirebon : bakteri (IKM/5.4.11/SKI-CRB (Biokimia)), parasit (IKM/5.4.5/SKI-CRB (Mikroskopis) dan IKM/5.4.9/SKICRB (Mikroskopis)), jamur metode IKM/5.4.12/SKI-CRB (Mikroskopis). Identifikasi megolocytivirus menggunakan analisis polymerase chain reaction (PCR) mengacu pada BKIPM (2016).

\section{Uji kualitas air}

Parameter kualitas air yang diukur yaitu suhu dan $\mathrm{pH}$. Pengukuran parameter kualitas air dilakukan secara in situ kemudian dianalisis secara deskriptif.

\section{HASIL DAN PEMBAHASAN}

Timbulnya suatu penyakit pada lingkungan budidaya diakibatkan oleh ketidak seimbangan hubungan antara inang, lingkungan, dan patogen (Sarjito et al., 2013). 
Serangan penyakit pada ikan dapat berdampak terhadap tingginya angka kematian. Sentra Budidaya Ikan Gurami di Kota Purwokerto mengalami kematian induk ikan Gurami yang sangat tinggi. pada periode Agustus 2017 - Januari 2018 terjadi 2.450 ekor kematian induk ikan Gurami (Tabel 1). Data angka kematian pada induk ikan Gurami diperoleh berdasarkan dari hasil wawancara yang dilakukan dengan pembudidaya ikan Gurami Desa Beji.

Tabel 1. Data kematian induk ikan Gurami di sentra budidaya ikan Gurami, Desa Beji, Kecamatan Kedung Banteng, Kabupaten Banyumas, Jawa Tengah, periode Agustus 2017 - Januari 2018.

\begin{tabular}{clccc}
\hline No. & $\begin{array}{c}\text { Nama } \\
\text { Pembudidaya }\end{array}$ & $\begin{array}{c}\text { Jumlah } \\
\text { Induk Ikan }\end{array}$ & $\begin{array}{c}\text { Jumlah Induk Ikan } \\
\text { Gurami yang Mati }\end{array}$ & $\begin{array}{c}\% \\
\text { Mortalitas }\end{array}$ \\
\hline 1 & Darso & 200 & 170 & 85 \\
2 & Surya & 500 & 400 & 80 \\
3 & Soleh & 100 & 100 & 100 \\
4 & Amad & 100 & 100 & 100 \\
5 & Diro & 1000 & 800 & 80 \\
6 & Eko & 150 & 130 & 87 \\
7 & Komari & 200 & 150 & 75 \\
8 & Kasan & 150 & 120 & 80 \\
9 & Kiman & 50 & 50 & 100 \\
10 & Darto & 200 & 200 & 100 \\
11 & Karsono & 150 & 130 & 87 \\
12 & Taryo & 100 & 100 & 100 \\
\hline
\end{tabular}

Berdasarkan dari hasil keberadaan patogen infeksius penelitian yang dilakukan pada 12 (Anderson, 1974). Kondisi pembudidaya ikan Gurami di Desa lingkungan yang buruk berdampak Beji, diketahui bahwa tingkat pada stres dan menurunnya sistem mortalitas dari induk Gurami sangat imun pada ikan yang mengakibatkan tinggi diatas $70 \%$. Tingginya angka kematian pada ikan Gurami yang terjadi dapat dikaitkan dengan interaksi kompleks antara faktor ikan mudah terserang penyakit (Baticados dan Paclibare, 1992). Kualitas air yang baik dapat lingkungan, inang dan faktor (Sutiknowati, 2012). 
Tabel 2. Kualitas air pada Budidaya ikan Gurami di sentra budidaya ikan Gurami, Desa Beji, Kecamatan Kedung Banteng, Kabupaten Banyumas, Jawa Tengah, periode Agustus 2017 - Januari 2018.

\begin{tabular}{ccc}
\hline \multirow{2}{*}{ Waktu } & \multicolumn{2}{c}{ Parameter Kualitas air } \\
\cline { 2 - 3 } & Suhu $\left({ }^{\circ} \mathrm{C}\right)$ & $\mathrm{pH}$ \\
\hline 05.30 & $24,5-25,6$ & 8,5 \\
12.30 & $25,6-26$ & 8,6 \\
15.00 & $26,7-29,5$ & 8,6 \\
21.00 & $25,7-26$ & 8,6 \\
24.00 & $25-28,5$ & 8,3 \\
\hline
\end{tabular}

Berdasarkan pada tabel 2, diketahui bahwa suhu berkisar antara 25,6 - $27{ }^{\circ} \mathrm{C}$ dan derajat keasaman $(\mathrm{pH})$ berkisar antara antara 8,3-8,6. Suhu optimal untuk budidaya ikan Gurami menurut Mulyana et al. (2013), yaitu berkisar antara 28-30 ${ }^{\circ} \mathrm{C}$. Hasil ini menunjukkan bahwa suhu pada pemeliharaan ikan Gurami di Desa Beji berada pada kondisi di bawah optimal. Suhu di bawah $28{ }^{\circ} \mathrm{C}$ akan berdampak pada menurunnya konsumsi pakan ikan Gurami (Sarjito et al., 2013). Menurunnya konsumsi pakan pada ikan akan berdampak pada menurunnya sistem imun ikan, laju pertumbuhan ikan serta menurunnya kualitas telur yang dihasilkan oleh induk ikan. Menurut Royan dan Haditomo (2014), kualitas air yang kurang baik akan berdampak pada menurunnya tingkat konsumsi pakan dan mengakibatkan kadar hematokrit ikan menurun.
Berdasarkan dari hasil penelitian diketahui bahwa sampel induk ikan Gurami menunjukkan beberapa gejala terserang penyakit seperti sirip ekor berwarna putih dan geripis, timbul bintik merah yang dimulai dari sirip ekor menyebar ke seluruh badan, warna tubuh pucat, sisik lepas timbul borok, dan ikan terlihat kurus. Hasil identifikasi patogen pada ikan Gurami di desa Beji menunjukkan adanya infeksi oleh Bakteri (Aeromonas hydrophila, Aeromonas sorbia), Parasit (Henneguya sp., Trichodina sp., Vorticella sp.), dan Jamur (Aspergillus sp.). Pada tabel 3, hasil identifikasi menggunakan PCR pada induk ikan Gurami menunjukkan negatif (-) artinya tidak terinfeksi megalocytivirus. Sementara kasus kematian induk Gurami dikaitkan dengan serangan megalocytivirus (Koesharyani dan Gardenia, 2013). 
Tabel 3. Identifikasi patogen pada induk ikan Gurami di sentra budidaya ikan Gurami, Desa Beji, Kecamatan Kedung Banteng, Kabupaten Banyumas, Jawa Tengah, periode Agustus 2017 - Januari 2018.

\begin{tabular}{llc}
\hline Jenis Patogen & Metode Uji & Hasil Uji \\
\hline Bakteri & & \\
\hline Aeromonas hydrophila & (IKM/5.4.11/SKI-CRB (Biokimia) & + \\
Aeromonas Sobria & (IKM/5.4.11/SKI-CRB (Biokimia) & + \\
\hline Parasit & & + \\
\hline Henneguya sp. & (IKM/5.4.5/SKI-CRB (Mikroskopis) & + \\
Thricodina sp. & IKM/5.4.9/SKI-CRB (Mikroskopis) & + \\
Vorticella sp. & IKM/5.4.9/SKI-CRB (Mikroskopis) & + \\
\hline Jamur & & + \\
\hline Aspergillus sp. & IKM/5.4.12/SKI-CRB (Mikroskopis) & + \\
\hline Virus & & \\
\hline Megalocytivirus & PCR (BKIPM, 2016) & \\
\hline
\end{tabular}

Serangan oleh bakteri $A$. hydrophila dan A. sorbia pada ikan menyebabkan penyakit Motile Aeromonas Septicemia (MAS). Dampak dari terjadinya penyakit MAS pada ikan Gurami menyebabkan haemoragik pada sirip dan sekitar mulut, pembengkakan ginjal, dan terkumpulnya sejumlah besar cairan pada rongga perut yang dapat mempengaruhi produksi telur pada ikan Gurami. Menurut Mulia (2013), gejala eksternal serangan $A$. hydrophila mengakibatkan insang dan tubuh memucat, disertai bercak merah (haemoragik) pada bagian punggung, belakang operculum, sirip, dan bagian tubuh lain. Serangan penyakit MAS juga dapat menyebabkan kematian ikan Gurami dengan prosentase yang tinggi yaitu berkisar antara $87-100 \%$.

$$
\text { Parasit juga merupakan }
$$
patogen yang dapat menyebabkan dampak serius pada kegagalan budidaya ikan. Trichodina sp. merupakan patogen penyebab penyakit Trichodiniasis. Pada penelitian ini dapat diketahui dampak dari serangan Trichodina sp. antara lain yaitu perubahan warna sisik menjadi lebih kusam dan terdapat 
Journal of Aquaculture Science

DOI: https://doi.org/10.31093/joas.v3i2.53
April 2018 vol 3 (2): 46-54

Online pada http://joas.co.id sisik yang mengelupas atau lepas.

Senada dengan hasil penelitian

Nurrochmah et al. (2016), menyatakan bahwa serangan parasit

Trichodina sp. dapat menyebabkan sisik lepas dan warna sisik menjadi kusam. Selain itu, menurut Woo (1991), mengungkapkan bahwa serangan penyakit Trichodiniasis dapat menyebabkan kematian pada inang. Parasit Henneguya sp. dapat menyerang ikan dan menyebabkan haemoragik yang merupakan manifestasi dari sistem pertahanan ikan. Lebih lanjut akan menimbulkan luka dan borok pada ikan. Menurut Gratzek (1993) infeksi Henneguya sp. dapat menimbulkan kista pada lamella dan mengganggu aliran darah di insang yang berdampak pada hiperplasia dan kematian Serangan parasit Vorticella sp. pada ikan berdampak pada menurunnya nafsu makan serta menggganggu pergerakan ikan apabila kepadatannya tinggi. Selain itu ikan yang terserang parasit Vorticella sp. terlihat gejala klinis sirip ikan geripis (Jithendran et al., 2010).

Berdasarkan dari hasil penelitian ini juga terdapat serangan jamur Aspergillus sp. pada ikan
Gurami. Jamur Aspergillus sp. memiliki mikotoksin yang berbahaya pada ikan dan hewan lainnya bahkan pada manusia. Aflatoksin merupakan mikotoksin Aspergillus sp. yang dapat menyebabkan nekrosis sel hati dan ginjal pada konsentrasi rendah (Safika, 2008) serta infeksi akut dan kematian pada konsentrasi tinggi (Guevara, 2011).

\section{KESIMPULAN}

Penyebab terjadinya kematian massal induk ikan Gurami di sentra budidaya ikan Gurami, Desa Beji, Kecamatan Kedung Banteng, Kabupaten Banyumas, Jawa Tengah disebabkan oleh serangan Bakteri (Aeromonas hydrophila, Aeromonas sorbia), Parasit (Henneguya sp., Trichodina sp., Vorticella sp.), dan Jamur (Aspergillus sp.).

Guna menanggulagi atau mencegah terjadinya kasus kematian massal pada induk ikan Gurami perlu dilakukan monitoring dan menjaga kualitas air secara berkala untuk memastikan kualitas air terjaga optimal guna meminimalisir terjadinya stress pada ikan yang menyebabkan patogen mudah 
Journal of Aquaculture Science

DOI: https://doi.org/10.31093/joas.v3i2.53

menginfeksi pada induk ikan

Gurami.

\section{DAFTAR PUSTAKA}

Anderson, D. P. 1974. Diseases of fishes. TRH Publication Inc. Ltd. Hongkong.

Badan Karantina Ikan, Pengendalian Mutu dan Keamanan Hasil Perikanan (BKIPM). 2016. Petunjuk Teknis Surveilan Megalocityvirus pada Ikan Hias Air Tawar dan Laut. KKP RI.

Baticados, M.C.L. and J.O. Paclibare. 1992. The use of chemotherapeutic agents in aquaculture in the Philippines. Diseases in Asian Aquaculture. 1. Proceedings of the First Symposium on Diseases in Asian Aquaculture, 26-29 November 1990, Bali, Indonesia.

Effendi, I., Bugri, H.J., Widanarni. 2006. Pengaruh padat penebaran terhadap kelangsungan hidup dan pertumbuhan benih ikan gurami Osphronemus gouramy lac. Ukuran 2 $\mathrm{cm}$. Jurnal Akuakultur Indonesia 5(2): 127-135.

Gratzek, J.B. 1993. Paracites Associated with Fresh Water Tropical Fish. In Fish medicine (Steskopf, M.K., ed.), pp. 573-590. Philadelphia: W.B. Sauders.

Guevara, R. G. 2011. Aflatoxin-Biochemistry and Molacular Biology. Intech. Croatia. Hal 221-234.

Sarjito, Prayitno, S.B., dan Haditomo, A.H.C. 2013. Buku Pengantar Parasit dan Penyakit Ikan. UPT UNDIP Press, Semarang.

Ismail, dan Khumaidi, A. 2016.Teknik Pembenihan Ikan Mas (Cyprinus carpio, L.) di Balai Benih Ikan (BBI) Tenggarang, Bondowoso. Samakia: Jurnal Ilmu Perikanan. Vol. 7 No. 1 : 27-37

Jithendran, K.P., Poornima, P., Balasubramanian, P., Kulasekarapadian, S. 2010. Disease
April 2018 vol 3 (2): 46-54

Online pada http://joas.co.id

of Mud Crabs (Scylla sp.): an overiew. Central institute of Brackishwater Aquaculture. Indian J. Fish, 57(3): 55-63.

Koesharyani, I., \& Gardenia, L. 2013. New Megalocytivirus Infected To The Cultured Fresh Water Giant Gourami, Osphronemus gouramy Lac. In Indonesia. Indonesian Aquaculture Journal, 8(1).

Mulia, S. D. 2013. Isolasi, Karakterisasi, dan Identifikasi Bakteri Aeromonas sp. Penyebab Penyakit Motile Aeromonas Septicemia (MAS) pada Gurami. Sains Akuatik 13 (2): 9-17.

Mulyana, Rosmawati, Mutikhasary, A. 2013. Penambahan Bunga Rosela (Hibiscus sabdariffa L.) pada Pakan Terhadap Ketahanan Tubuh Ikan Gurami (Osphronemus gouramy) yang Diuji Tantang Dengan Bakteri Aeromonas hydrophila. Jurnal Pertanian 4 (1), 26-32.

Nurrochmah, H.S., Rokhmani, Riwidiharso, E. 2016. Kelimpahan dan Variasi Morfometrik Trichodina sp. pada Benih Ikan Gurami (Osphronemus gouramy LAC.) di Kolam Budidaya Desa Baji Kecematan Kedungbanteng Banyumas. Seminar Nasional Pendidikan dan Saintek 2016.

Putri, M. R. A., Hartati, S. T., \& Satria, F. 2016. Kematian Massal Ikan dan Sebaran Parameter Kualitas Air di Teluk Jakarta (Mass Fish Kills in Jakarta Bay and Waters Quality Parameters in Jakarta Bay). Bawal Widya Riset Perikanan Tangkap, 8 (2), 77-90.

Rudiono, Harsasto P, Taufiq A. 2014. Evaluasi Pelaksanaan Program Minapolitan Tahun 2009 - 2011 di Kabupaten Banyumas. Jurnal Ilmu Pemerintahan, 3 (1), 1-8.

Safika. 2008. Korelasi Aspergillus flavus dengan Konsetrasi Aflatoksin B1 pada Ikan Kayu. Unsyiah Banda Aceh. Jurnal Kedokteran Hewan 2 (2): 171-173. 
Malika, U.E., Tejasari, Hani, E.S. 2012. Perumusan Strategi Peningkatan Mutu Teknik Produksi Ikan Gurami (Osphronemus Gouramy) Berdasarkan Metode Force Field Analysis (FFA). JSEP Vol. 6 No.1 Maret : 12-19

Sutiknowati, L.I. 2012. Kualitas Air yang Mendukung Potensi Budidaya di Perairan Pesisir Pulau Pari: Aspek Mikrobiologi. J. Segara Vol. 8 No. 2.

Tanjung, L. R., Said, D. S., Triyanto, \& Maghfiroh, M. 2016. Ikan Gurami ( Osphronemus gouramy ) Strain Padang Terbukti Memiliki Ketahanan Alami terhadap Infeksi Aeromonas. In Konferensi Akuakultu Indonesia 2013.

Woo, J. L., 1991. Fish Disease and Disorder Parasite. Canada: University of Guelph. CAB. International. 